\title{
Essential aspects in the design of data collection instruments in primary health research
}

Débora Butka Thomas ${ }^{(1)}$ Nágila Soares Xavier Oenning ${ }^{(1)}$

Bárbara Niegia Garcia de Goulart(1)

(1) Universidade Federal do Rio Grande do Sul, Porto Alegre - RS, Brasil. Research support source: National Council for Scientific and Technological Development - CNPq and Foundation for Research Support of the State of Rio Grande do Sul - FAPERGS.

Conflict of interests: Nonexistent

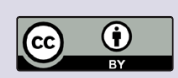

Received on: March 5, 2018 Accepted on: September 11, 2018

Corresponding address: Bárbara Niegia Garcia de Goulart Rua Ramiro Barcelos, $2400,2^{\circ}$ andar CEP: 90035-003 - Porto Alegre, Rio Grande do Sul, Brasil

E-mail: bngoulart@gmail.com

\section{ABSTRACT}

Objective: to investigate the literature production on the design of forms for research in the health area and describe the most relevant concepts and precepts of the topic.

Methods: an integrative literature review in the PubMed and Scielo databases with the key words: survey, constructing, questionnaire, formulary, development and design in various combinations, including articles published in any language in the last ten years. The survey returned 1,480 articles, and after reading and critically reviewing the abstracts according to the objective of the study, 16 articles were selected for complete reading. Information regarding aspects that were most relevant to the objective of the study was analyzed, as well as its recurrence in the selected articles.

Results: the reading of the 16 articles resulted in three categories, based on the recurrence of the themes: structure, validation and sampling.

Conclusion: clarity in the formulation of the questions was the most valued aspect in the structure of the instrument. As for validation, the realization of pilot tests was considered fundamental. Finally, the method of administration and adaptation of the questionnaire to target population was considered fundamental.

Keywords: Health Surveys; Surveys and Questionnaires; Methodology; Review 


\section{INTRODUCTION}

Health research involving human beings consists of generating new knowledge through the use of the scientific method to identify and deal with health problems. Knowledge acquired through research is considered a global public good ${ }^{1}$. The Committee for Health Research and Development, created in 1987 based on the premise of comprehensive analysis of health conditions and health research, pointed out that research is essential for health actions and health promotion, and it is also necessary to contribute to new ideas and alternative interventions ${ }^{2}$.

In Latin America, health research is concentrated in some countries, that happen to be the largest economies: Mexico, Chile, Brazil and Argentina. These countries contribute with $90 \%$ of the total Latin American investment in research and development ${ }^{3}$. Among Latin American countries, Brazil has a high production in the areas of public health, biotechnology and pharmacy. Over the past two decades, the focus on reducing poverty, child and maternal mortality, and combating HIV, malaria and other diseases has given impetus to improvements in health care and investments in this area. The understanding is that investments in health research have a direct effect on meeting the aforementioned goals ${ }^{3}$.

Scientific research requires extensive planning, human and material resources, time and effort. The application of instruments such as questionnaires and forms is an effective way to collect population data with relative logistical practicality.

Health research instruments are essential tools to gather information from individuals thatrepresent a given population since health research has diverse objectives, from those focused on experiments (e.g. search for a new drug treatment, a new intervention), to those of observational nature (e.g. assessment of risk factors, assessment of quality of health care, description of indicators). Each objective of health research should be interconnected to the feasible dimensions. For example, the study of patient perceptions regarding health treatments is an important tool to identify strengths, weaknesses and unmet needs in health services as well as to identify changes in patient satisfaction over time ${ }^{4,5}$.

For the development of scientific research with primary sources, it is necessary to formulate clear and functional instruments during the planning stage of the study. They should contemplate questions that will originate variables to enable a response directly associated with the objectives of the study. In addition to assessing what they are proposing, they should have stability, i.e., they should present similar results in test and retest when subjects are in the same health condition ${ }^{6}$. Some errors are recurrent in this field; some of them are related to the layout of the instrument: too small font size; too long instrument; selection of an opportunistic sampling that excludes certain groups that would be of interest to the research ${ }^{7}$.

The design of an instrument is an extremely important aspect to ensure that the data will be accurately collected and the results will be interpretable and generalizable ${ }^{6}$. The form of application (postal delivery, telephone, face-to-face or the Internet), taking into account the particularities of the study design ${ }^{6}$ appropriately targeted to the study population, as well as validation, are also questions to be evaluated for the creation of effective and efficient instruments. All this must be taken into account, since a biased tool sent to an unrepresentative sample will not provide useful information, but rather distort the possible actual results of the research.

The reality of health research, especially of observational nature, is that studies do not always present adequate rigor for the creation of research instruments, this fact is observed in publications of studies whose data collection tools are not validated and/or their interpretations are not clear, leading to unintelligible data or erroneous conclusions ${ }^{8}$.

Given the importance of planning in research, the objective of this study is to survey the literature on the design of health research forms and describe the most relevant concepts and precepts of the theme.

\section{METHODS}

Thisis a study with data collection from secondary sources, through an integrative review of the literature performed in the Scielo and Pubmed databases. The keywords "survey", "constructing", "questionnaire", "formulary", "development" and "design" were used, resulting in 1,480 indexed articles with selection filter set for articles published from 2006 to 2016, in any language, and without design restriction. After reading and critically analyzing the titles and abstracts, taking into account the proximity to the objective of the present research, the articles that did not present in the description the context of design of questionnaires/instruments/forms and/or validation studies were excluded. At the end, 16 articles were selected. The selected articles were read in full length, and 
the information on journal and year of publication, objective, type of study involving the elaboration of the research instrument, aspects considered for the elaboration of the research instrument, bias of assessment, attention to the application of a pilot study to test the instrument of data collection, and influence of the type of population onthe application of instruments, were factors to be considered, among others. The content was categorized according to the aspects most relevant to the nature of this work and the frequency in which it appeared in the selected literature. Methodological and theoretical issues associated with the preparationof a health research instrument were evaluated and a list of guidelines for decision making at each stage of such development were presented (Figure 1).

\begin{tabular}{|c|c|c|}
\hline Search strategy & Initial result & Result after analysis \\
\hline $\begin{array}{l}\text { SURVEY [Title/Abstract] AND Constructing [Titte/Abstract] AND } \\
\text { ("2006/04/23"[PDAT] : "2016/04/19"[PDAT]) -PUBMED }\end{array}$ & 201 & 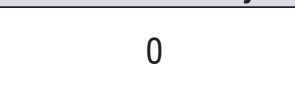 \\
\hline $\begin{array}{l}\text { ((survey[Title/Abstract] OR QUESTIONNAIRE[Title/Abstract]) } \\
\text { OR formulary[Titte/Abstract]) AND designing[Title] AND } \\
\text { ("2006/04/23"[PDAT] : "2016/04/19"[PDAT]) -PUBMED }\end{array}$ & 115 & 9 \\
\hline $\begin{array}{l}\text { (survey[Title] OR questionnaires[Title]) AND development [Title] } \\
\text { AND ("2006/04/24"[PDat] : "2016/04/20"[PDat]) -PUBMED }\end{array}$ & 581 & 2 \\
\hline (ti:((questionnaire) AND (elaboration ) OR (design ))) -SCIELO & 583 & 0 \\
\hline $\begin{array}{l}\text { Questionnaire [Title] AND developing [Title] AND } \\
\text { ("2006/04/30" [PDat] : "2016/04/26"[PDat]) }\end{array}$ & 61 & 0 \\
\hline Similar articles for PubMed (Select 17239058) & 419 & 5 \\
\hline
\end{tabular}

Figure 1. Summary of search strategies in Pubmed and Scielo

\section{LITERATURE REVIEW}

\section{Main findings}

Among the 16 selected articles, three distinct categories were found based on the recurrence of the themes: structure, validation and sampling (population studied). Aspects related to the structure were described in 10 articles (62.5\%); those related to the population (subjects of the research/sampling/form of administration) appeared in 10 (62.5\%); aspects related to validation appeared in 8 articles (50\%), with emphasis on pilot studies that were recurrent in $75 \%$ of articles that addressed validity. Each aspect wasthen discussed and the most relevant concepts were highlighted.

\section{Structure}

Before preparing a new instrument, it is recommended that a literature review be done to verify if there is no validated instrument for the theme in question; if a data collection tool (research tool) needs to be created, a search in the literature for the recommended scale and items (categories) more relevant to respond to the purpose of the study should be done. In quantitative studies, once the main research items are defined, the questions should be prepared so as to provide variables on each of these items, whereas in qualitative studies they should provide answers that are coherent with the guiding question without the need for systematized items ${ }^{7,8}$.

An instrument with an adequate structure should consider the type of question (objective, subjective), the language used, which must be appropriate for the studied population and the order of the items. Questions should be formulated so as to ensure that each is easy to understand, free from information bias, and appropriate to the level of education and culture of the participants ${ }^{7-9}$.

Given that the order of the questions influences the answers, the literature indicates that questions should be organized from the easiest to the most difficult; from the general to the specific; from the factual to the abstract. Clinical and demographic data should be left to the end of the instrument because they are easier and potentially intrusive $e^{5,6,9,10}$. Controversial or emotive items should not be placed at the beginning of the instrument 5,9 .

In addition to the questions, researchers should consider the best response format (open, closed, dichotomous, multiple choice, ordinal, among others). 
In cases of scale, the choice should be designed to contribute positively to data collection and to the purpose of the study $y^{7,11}$.

Closed questions are easier to analyze and apply, but the downside is that they reduce the number of possible responses. This way of questioning can provide summary information and reduce the misinterpretation bias of what was written by the participants. In turn, open questions allow respondents to put their own answers that increase the range of possible answers and of individuality. With these type of questions, researchers can often measure the importance of a particular subject better, but the analysis and comparison is challenging. In general, an effort needs to be put to the formulation of objective questions, while in the case of open questions, the effort will be concentrated on data interpretation; the fact is that the choice for either of the options will depend on the objective and the study design $5,5,8,10$.

\section{Validation}

Validity is the degree of congruence between what the instrument proposes to measure and what it actually measures; a valid tool should question what the researcher wants to ask and the questions should be formulated in such a way that the interviewee understands the purpose of the question.

There are four different dimensions in the validity of an instrument: apparent validity (logical dimension), content validity (face), concept or construct validity, and criterion validity ${ }^{12}$.

Apparent validity (or logical dimension) refers to the extent to which it seems that the instrument measures what it proposes to measure in the view of specialists and of the subjects themselves. This validity must be verified at the time of structuring the instrument, because when the issues do not have logical validity, it is highly likely that individuals will refuse to answer the questions. However, in specific cases, in order to achieve apparent validity, the instrument must undergo a pilot test with the target population (e.g. if the target respondents are diabetic patients, so one of these respondents should comment on his understanding of the instrument). Any uncertainties and doubts should be clarified until the question becomes easy to understand. When instruments are extensively tested and correctly calibrated for their target, they can be considered accurate ${ }^{5,6}$. In some cases, it may be interesting to formulate questions without logical validity, because in sensitive or controversial issues, the use of questions with too much apparent validity may cause the subjects decide not to respond or distort their response ${ }^{12}$.

Content validity (or face validity) refers to the opinion of the expert on whether the items in the scale represent the domains or concepts proposed for the research. It is therefore considered that an instrument is valid if it considers all aspects related to the concept studied. For example, a teacher gives a course consisting of five classes, each with a different content, and he decides to evaluate how much the students learned through a test. In order for the content to be valid, the testmust contain a set of questions that is representative of the contents given in all the five classes, with the same number of questions about each class $^{13}$. This dimension of validity is related to the composition of an instrument; it evaluates whether it contains a representative sample of the components of the construct to be measured. This validation involves the systematic analysis of the contents of the measuring instrument to determine whether the questions are relevant and the essential characteristics of the construct are represented in the appropriate proportions. Content validity assessment is based on judgments from different sources (review of medical literature, expert opinion, pilot studies) ${ }^{8,9}$.

The validity of a construct (or concept validity) evaluates the extent to which the instrument reflects the theory of the phenomenon or of the concept to be measured. It ensures that the measurements resulting from the responses can be considered and used as a measure of the phenomenon studied. The measurement of the theoretical concepts requires the prior identification of the content of the instruments that they used and the elaboration of a conceptual model to help interpret the obtained results. That is, if a test that intends to measure speech changes, whether phonetic or phonological deviations, effectively measures such changes, as proposed by TERDAF ${ }^{14}$ or it has concept validity. Factor analysis is a statistical technique that can be used to determine the constructs or domains in the developing measure, that is, it groups responses according to the underlying factors ${ }^{9,12}$.

Criterion validity is the type of validity that is commonly referred to when validating an instrument. It involves the following steps: identifying a relevant and reliable external criterion; obtaining a representative sample of the subject for the population in which the instrument will be used; applying the instrument and obtaining a score for each subject, and evaluating each of the individuals with the external reference value ${ }^{12}$. For 
example, for an instrument that evaluates intelligence, a relevant criterion could be school performance ${ }^{13}$.

A valid instrument, whether questionnaire or form, should be simple, feasible and acceptable to patients, users and researchers (viability); reliable and accurate (reliability); appropriate to the research problem (content validity); reflecting the theory underlying the phenomenon or concept to be measured (construct validity); and able to measure changes, both in different individuals and in the responses of a single individual over time (sensitivity to changes) ${ }^{8,12}$.

Sampling (research subjects/form of administration)

Once the research question is defined, the target population must be established ${ }^{7}$, which can have people, houses, organizations or other aggregates as a unit, in order to enable the researchers to achieve the planned objectives, including the design and application of the instrument. After this step, and according to the study design and structure of the research, the sampling method should be defined.

As for data collection, the research tools can be self-administered or interviews can be applied via facilitator (interviewer). Self-administered instruments are more widely used. They must have clear instructions and questions and follow a logical order to ensure a high response rate, which is lowerin this method when compared to other ones. However, respondents are more likely to respond sincerely without the presence of an interviewer. On the other hand, when an instrument is applied by an interviewer, the questions canbe more complex, as they can be clarified. However, the presence of an interviewer may pressure respondents to give what they deem to be "appropriate" rather than true answers. Furthermore, this last method consumes much more time and resources. The form of administration must be adapted to the target population, to the research resource structure, and to what is intended to be achieved with the application of the instrument ${ }^{5,6}$.

Poor data collection is a barrier to high-quality research is ${ }^{15}$ because no statistical technique, no matter howsophisticated it is, can correct data whose collection was poorly planned. The data collected must be truly capable of responding to the question of interest and all relevant information must be recorded in a way that allows it to be easily used for further analysis. Poorly designed forms often have high levels of missing data. An obvious consequence is that this reduces the number of individuals that can be included in the study and consequently the possibility of an effect being detected, if it exists. The scriptfor collecting secondary data (for example, searching for information in medical records) should also be systematized and, as far as possible, follow the aspects described above.

Figure 2 describes the main themes described in each integrative review study. 


\begin{tabular}{|c|c|c|c|c|}
\hline $\begin{array}{c}\text { Journal/Year of } \\
\text { publication }\end{array}$ & Author (s) & Title of the article & Objectives & Description \\
\hline $\begin{array}{l}\text { Archives of Disease } \\
\text { in Childhood } \\
\text { Education, } 2016\end{array}$ & $\begin{array}{l}\text { Thwaites Bee, D. } \\
\text { and Murdoch- } \\
\text { Eaton, D. }{ }^{(7)}\end{array}$ & $\begin{array}{l}\text { Questionnaire design: } \\
\text { the good, the bad and } \\
\text { the pitfalls. }\end{array}$ & $\begin{array}{l}\text { To describe the development of a ques- } \\
\text { tionnaire: advantages, disadvantages } \\
\text { and challenges. }\end{array}$ & $\begin{array}{l}\text { It shows considerations about sam- } \\
\text { pling; design, types of questions/sca- } \\
\text { les; administration and pilot test. Exam- } \\
\text { ples of what to do (or not to do) in this } \\
\text { process are presented. }\end{array}$ \\
\hline $\begin{array}{l}\text { Nurse Researcher, } \\
2016\end{array}$ & $\begin{array}{c}\text { Doody, } \\
\text { 0.,Bailey,M.E. }{ }^{(16)}\end{array}$ & $\begin{array}{l}\text { Setting a research } \\
\text { question, aim and } \\
\text { objective. }\end{array}$ & $\begin{array}{l}\text { To describe the development of a rese- } \\
\text { arch question, objective and purpose. }\end{array}$ & $\begin{array}{l}\text { It presents considerations regarding } \\
\text { the development of a research question } \\
\text { and its objectives, and subsequently of } \\
\text { the types of questions/scales; sample; } \\
\text { administration and pilot test. }\end{array}$ \\
\hline $\begin{array}{l}\text { Journal of Korean } \\
\text { Academy of } \\
\text { Nursing, } 2015\end{array}$ & Song,Y.et al. ${ }^{(11)}$ & $\begin{array}{l}\text { Methodological issues } \\
\text { in questionnaire design. }\end{array}$ & $\begin{array}{l}\text { To discuss the design of questionnaires } \\
\text { and the factors that should be conside- } \\
\text { red when using existing scales. }\end{array}$ & $\begin{array}{l}\text { It describes the process of preparing } \\
\text { questionnaires and adapting existing } \\
\text { ones, as well asaspects related to ad- } \\
\text { ministration; design; pilot test; sample } \\
\text { and combination of qualitative and } \\
\text { quantitative methods. }\end{array}$ \\
\hline $\begin{array}{c}\text { BMC Medical } \\
\text { Research } \\
\text { Methodology, } 2014\end{array}$ & $\begin{array}{l}\text { Dell-Kuster, S. } \\
\quad \text { et al. }{ }^{(4)}\end{array}$ & $\begin{array}{l}\text { Designing } \\
\text { questionnaires: } \\
\text { healthcare survey to } \\
\text { compare two different } \\
\text { response scales. }\end{array}$ & $\begin{array}{l}\text { To intra-individually compare two types } \\
\text { of response scales to five general } \\
\text { questions to assess patient perception } \\
\text { of hospital care. }\end{array}$ & $\begin{array}{l}\text { It presents types of scales/questions } \\
\text { (design); intra-individually compares } \\
\text { responses on two types of scales. }\end{array}$ \\
\hline $\begin{array}{l}\text { Annals of the } \\
\text { Royal College } \\
\text { of Surgeons of } \\
\text { England, } 2013\end{array}$ & $\begin{array}{l}\text { Jones, T.L. } \\
\text { et al. }{ }^{(17)}\end{array}$ & $\begin{array}{l}\text { A quick guide to survey } \\
\text { research. }\end{array}$ & $\begin{array}{l}\text { To address the key aspects of desig- } \\
\text { ning, implementing and analyzing a re- } \\
\text { search, as well as focus on techniques } \\
\text { that improve response rates. }\end{array}$ & $\begin{array}{l}\text { It describes guidelines on how to as- } \\
\text { semble, apply and analyze instruments } \\
\text { based on administration; design; pilot } \\
\text { test; sample. }\end{array}$ \\
\hline Medicine 20, 2013 & $\begin{array}{l}\text { Jones, T.L. } \\
\text { et al.(5) }\end{array}$ & $\begin{array}{l}\text { Development of a } \\
\text { questionnaire and } \\
\text { cross-sectional survey } \\
\text { of patient eHealth } \\
\text { readiness and eHealth } \\
\text { inequalities. }\end{array}$ & $\begin{array}{l}\text { To develop and validate a self-admi- } \\
\text { nistered questionnaire and a scoring } \\
\text { system to assess the patient's e-Health } \\
\text { readiness. }\end{array}$ & $\begin{array}{l}\text { It demonstrates the preparation of a } \\
\text { self-administered questionnaire, inclu- } \\
\text { ding sampling, administration and pilot } \\
\text { testing. }\end{array}$ \\
\hline $\begin{array}{c}\text { Journal of the } \\
\text { Pakistan Medical } \\
\text { Association, } 2012\end{array}$ & $\begin{array}{l}\text { Kazi, A.M. and } \\
\text { Khalid, W. }{ }^{(10)}\end{array}$ & $\begin{array}{l}\text { Questionnaire designing } \\
\text { and validation. }\end{array}$ & $\begin{array}{l}\text { To provide a basic introduction and } \\
\text { overview of questionnaires for epide- } \\
\text { miological studies. }\end{array}$ & $\begin{array}{l}\text { It provides examples of common pro- } \\
\text { blems, solutions and guidelines for de- } \\
\text { veloping and adapting questionnaires, } \\
\text { such as: types of questions; language; } \\
\text { design; administration; validation and } \\
\text { pilot test. }\end{array}$ \\
\hline $\begin{array}{l}\text { Journal of Trauma } \\
\text { and Acute Care } \\
\text { Surgery, } 2012\end{array}$ & $\begin{array}{l}\text { Bobrovitz, N. } \\
\text { et al. }{ }^{(18)}\end{array}$ & $\begin{array}{l}\text { The development and } \\
\text { testing of a survey to } \\
\text { measure patient and } \\
\text { family experiences with } \\
\text { injury care. }\end{array}$ & $\begin{array}{l}\text { To develop and test a research ins- } \\
\text { trument to measure the patient's and } \\
\text { family's experiences with treatment of } \\
\text { serious injuries. }\end{array}$ & $\begin{array}{l}\text { It describes the development and tes- } \\
\text { ting of a questionnaire to measure } \\
\text { traumatic experiences from the point } \\
\text { of view of the patient and the family. } \\
\text { It describes the use of pilot tests and } \\
\text { elucidates aspects of sampling and } \\
\text { validity. }\end{array}$ \\
\hline $\begin{array}{l}\text { Canadian Journal of } \\
\text { Anesthesia, } 2012\end{array}$ & $\begin{array}{l}\text { Bryson, G.L. } \\
\quad \text { et al. }{ }^{(9)}\end{array}$ & $\begin{array}{l}\text { The science of opinion: } \\
\text { survey methods in } \\
\text { research. }\end{array}$ & $\begin{array}{l}\text { To provide a guide for those conducting } \\
\text { surveys based on questionnaires and } \\
\text { for interested readers of surveys. }\end{array}$ & $\begin{array}{l}\text { It highlights several key principles of } \\
\text { successful research from the point of } \\
\text { view of the sample and the population, } \\
\text { as well as aspects about administra- } \\
\text { tion; pilot test; creation and reduction } \\
\text { of items. }\end{array}$ \\
\hline $\begin{array}{l}\text { Otolaryngology } \\
\text { - Head and Neck } \\
\text { Surgery, } 2011\end{array}$ & $\begin{array}{l}\text { Slattery, E.L. } \\
\text { et al. }{ }^{(19)}\end{array}$ & $\begin{array}{l}\text { A practical guide } \\
\text { to surveys and } \\
\text { questionnaires. }\end{array}$ & $\begin{array}{l}\text { To present a practical guide to unders- } \\
\text { tand the research methodologies and } \\
\text { the design of questionnaires, including } \\
\text { the concepts of validity and reliability, } \\
\text { and how surveys are administered. }\end{array}$ & $\begin{array}{l}\text { In addition to addressing topics such } \\
\text { as: design; order and structure; sam- } \\
\text { ple; administration; validity and reliabi- } \\
\text { lity; and pilot testing, it also deals with } \\
\text { possible biases in assessment. }\end{array}$ \\
\hline Phlebology,2011 & Smith, C.J. ${ }^{(15)}$ & $\begin{array}{l}\text { Designing a research } \\
\text { study. }\end{array}$ & $\begin{array}{l}\text { To analyze the design and data collec- } \\
\text { tion phases of a research study. }\end{array}$ & $\begin{array}{l}\text { It addresses the phases of conception } \\
\text { and data collection of a research study, } \\
\text { demonstrating questions about popula- } \\
\text { tion, sample and administration. }\end{array}$ \\
\hline
\end{tabular}




\begin{tabular}{|c|c|c|c|c|}
\hline $\begin{array}{c}\text { Journal/Year of } \\
\text { publication }\end{array}$ & Author (s) & Title of the article & Objectives & Description \\
\hline $\begin{array}{l}\text { Journal of } \\
\text { Wound Ostomy } \\
\text { \& Continence } \\
\text { Nursing, } 2010\end{array}$ & $\begin{array}{l}\text { Pittman, J., } \\
\text { Bakas, T. }{ }^{(20)}\end{array}$ & $\begin{array}{l}\text { Measurement and } \\
\text { instrument design. }\end{array}$ & $\begin{array}{l}\text { To discuss the theoretical issues that } \\
\text { are fundamental for the development } \\
\text { of instruments, including conceptual } \\
\text { models, selection of instrument types, } \\
\text { design and construction of question- } \\
\text { naires, establishment of content va- } \\
\text { lidity, determination of reliability and } \\
\text { determination of validity. }\end{array}$ & $\begin{array}{l}\text { It describes fundamental theoretical } \\
\text { questions for the development of ins- } \\
\text { truments, design and construction of } \\
\text { questionnaires, and establishment of } \\
\text { reliability and validity. }\end{array}$ \\
\hline $\begin{array}{c}\text { Medical } \\
\text { Teacher,2009 }\end{array}$ & $\begin{array}{l}\text { Burford, B. } \\
\text { et al. }{ }^{(21)}\end{array}$ & $\begin{array}{l}\text { Asking the right } \\
\text { questions and getting } \\
\text { meaningful responses: } \\
12 \text { tips on developing } \\
\text { and administering } \\
\text { a questionnaire } \\
\text { survey for healthcare } \\
\text { professionals. }\end{array}$ & $\begin{array}{l}\text { To provide simple guidelines on some } \\
\text { of the potential pitfalls in the develop- } \\
\text { ment and execution of research stu- } \\
\text { dies, and how to avoid them. }\end{array}$ & $\begin{array}{l}\text { Twelve guidelines for formulating a } \\
\text { questionnaire are presented, among } \\
\text { them: design, sample and reliability, } \\
\text { validity and pilot test; and aspects of } \\
\text { financial and time planning, bringing } \\
\text { real examples of the situation in each } \\
\text { of the steps. }\end{array}$ \\
\hline $\begin{array}{l}\text { Reumatologia } \\
\text { Clínica, } 2009\end{array}$ & $\begin{array}{l}\text { García de Yébenes } \\
\text { Prous, M.A. } \\
\text { and Rodríguez } \\
\text { Salvanés, F.12) }\end{array}$ & $\begin{array}{c}\text { Validation of } \\
\text { questionnaires. }\end{array}$ & $\begin{array}{l}\text { To describe the methodology for a stu- } \\
\text { dy of feasibility, reliability and validity } \\
\text { of questionnaires: how scales or me- } \\
\text { asurement instruments allow obtaining } \\
\text { and quantifying data to compare infor- } \\
\text { mation. }\end{array}$ & $\begin{array}{l}\text { It gives details of the fundamental as- } \\
\text { pects of validity and reliability. }\end{array}$ \\
\hline $\begin{array}{l}\text { Journal of Clinical } \\
\text { Nursing,2007 }\end{array}$ & $\begin{array}{l}\text { Rattray,J. and } \\
\text { Jones, M.C. }{ }^{(8)}\end{array}$ & $\begin{array}{l}\text { Essential elements of } \\
\text { questionnaire design } \\
\text { and development. }\end{array}$ & $\begin{array}{l}\text { To raise awareness about issues re- } \\
\text { lated to the creation of questionnaires } \\
\text { and the subsequentpsychometric as- } \\
\text { sessment, and provide strategies to } \\
\text { enable researchers to design and deve- } \\
\text { lop their own instruments and assess } \\
\text { the quality of existing instruments. }\end{array}$ & $\begin{array}{l}\text { It addresses psychometric evaluation } \\
\text { issues and provides strategies to ena- } \\
\text { ble researchers to design and develop } \\
\text { questionnaires through different types } \\
\text { of questions/scales; creation and se- } \\
\text { lection of items; ordering of questions; } \\
\text { pilot test; validity, reliability and quality. }\end{array}$ \\
\hline $\begin{array}{l}\text { Malaysian Family } \\
\text { Physician,2006 }\end{array}$ & Jenn, NC. ${ }^{(6)}$ & $\begin{array}{c}\text { Designing a } \\
\text { Questionnaire. }\end{array}$ & $\begin{array}{l}\text { To describe guidelines for building } \\
\text { questionnaires and the implications of } \\
\text { not following them. }\end{array}$ & $\begin{array}{l}\text { It explains how to design a question- } \\
\text { naire considering the analysis of the } \\
\text { answers. It synthesizes aspects of } \\
\text { validity and reliability and pilot test; as } \\
\text { well as aspects linked to the design, } \\
\text { thetypes of questions and the order; } \\
\text { translation and administration. }\end{array}$ \\
\hline
\end{tabular}

Figure 2. Description of the main findings of each article of the integrative review

\section{CONCLUSION}

As for the structure, keeping the clarity in the formulation of the questions was the most valued aspect, while in validation, the realization of pilot tests stood out. As for the population, the way of administration (interview, the internet, among others) and the adaptation of the instrument to that sample of subjects were outstanding aspects. Proper planning of the health research form can minimize possible biases and errors in the conduction of the scientific studies.

\section{REFERENCES}

1. Canario JA, Lizardo J, Espinal R, Colomé M. Gaps in health research in the Dominican Republic. Rev
Panam Salud Publica Pan Am J Public Health. 2016;39(4):179-85.

2. Nuyens $\mathrm{Y}$. No development without research a challenge for research capacity strengthening. Genève (Suisse): Global Forum of Health; 2005.

3. Moloney A. Latin America faces hurdles in health research. The Lancet. 2009;374(9695):1053-4.

4. Dell-Kuster S, Sanjuan E, Todorov A, Weber H, Heberer M, Rosenthal R. Designing questionnaires: healthcare survey to compare two different response scales. BMC Med Res Methodol [Internet]. 2014 Dec [cited 2018 Feb 25];14(1). Available from: http://bmcmedresmethodol.biomedcentral.com/ articles/10.1186/1471-2288-14-96

5. Jones R. Development of a Questionnaire and Cross-Sectional Survey of Patient eHealth 
Readiness and eHealth Inequalities. Med 20. 2013;2(2):e9.

6. Jenn NC. Designing A Questionnaire. Malays Fam Physician Off J Acad Fam Physicians Malays. 2006;1(1):32-5.

7. Thwaites Bee D, Murdoch-Eaton D. Questionnaire design: the good, the bad and the pitfalls. Arch Dis Child - Educ Pract Ed. 2016;101(4):210-2.

8. Rattray J, Jones MC. Essential elements of questionnaire design and development. J Clin Nurs. 2007;16(2):234-43.

9. Bryson GL, Turgeon AF, Choi PT. The science of opinion: survey methods in research. Can J Anesth Can Anesth. 2012;59(8):736-42.

10. Kazi AM, Khalid W. Questionnaire designing and validation. JPMA J Pak Med Assoc. 2012;62(5):514-6.

11. Song Y, Son Y-J, Oh D. Methodological issues in Questionnaire Design. J Korean Acad Nurs. 2015;45(3):323.

12. Yébenes Prous MJG, Rodríguez Salvanés F, Carmona Ortells L. Validación de cuestionarios. Reumatol Clínica. 2009;5(4):171-7.

13. Hutz CS, Bandeira DR, Trentini CM (ed). Psicometria. Porto Alegre: Artmed Editora; 2015.

14. Goulart BNG de, Ferreira J. Speech disorder screening test for children. Pro-Fono $\mathrm{R}$ Atual. Cientif. 2009;21(3):231-6.
15. Smith CJ. Designing a research study. Phlebol J Venous Dis. 2011;26(8):369-70.

16. Doody O, Bailey ME. Setting a research question, aim and objective. Nurse Res. 2016;23(4):19-23.

17. Jones $T$, Baxter $M$, Khanduja V. A quick guide to survey research. Ann $R$ Coll Surg Engl. 2013;95(1):5-7.

18. Bobrovitz N, Santana MJ, Ball CG, Kortbeek J, Stelfox HT. The development and testing of a survey to measure patient and family experiences with injury care. J Trauma Acute Care Surg. 2012;73(5):1332-9.

19. Slattery EL, Voelker CCJ, Nussenbaum B, Rich JT, Paniello RC, Neely JG. A practical guide to surveys and questionnaires. Otolaryngol-Head Neck Surg. 2011;144(6):831-7.

20. Pittman J, Bakas T. Measurement and instrument design. J Wound Ostomy Continence Nurs. 2010;37(6):603-7.

21. Burford B, Hesketh A, Wakeling J, Bagnall G, Colthart I, Illing $\mathrm{J}$ et al. Asking the right questions and getting meaningful responses: 12 tips on developing and administering a questionnaire survey for healthcare professionals. Med Teach. 2009;31(3):207-11. 